\title{
TRACE ELEMENT CHARACTERIZATION IN HOUSEHOLD DUSTS IN INDUSTRIAL AREAS ALONG HIGHWAYS IN BANGLADESH AND THEIR HEALTH IMPLICATIONS
}

\author{
MD. BADIUZZAMAN KHAN ${ }^{1,}$, MD. REAZUL ISLAM ${ }^{1}$, BILKIS ARA BEGUM ${ }^{2}$, MD. ABDULLAHMIAH ${ }^{1}$
}

${ }^{I}$ Department of Environmental Science, Bangladesh Agricultural University, Mymensingh-2202, Bangladesh

\begin{abstract}
A study was carried out in the industrial areas in order to determine the composition of trace elements in dusts deposited at homes, identifying different sources of elements and also for their possible health impacts. A total of 14 deposited dust samples were collected from households near industrial areas of Tangail and Gazipur districts during sampling campaign. Samples were analyzed using $\mathrm{X}$-ray Fluorescence and the highest concentration was observed for Fe whereas the overall rank of the concentrations is $\mathrm{Fe}>\mathrm{Ca}>\mathrm{K}>\mathrm{Ti}>\mathrm{Zn}>\mathrm{Pb}>\mathrm{Zr}>\mathrm{Sr}>\mathrm{Rb}>\mathrm{Cu}>\mathrm{Y}>\mathrm{As}>\mathrm{Cr}>\mathrm{Ni}$. The Correlation analysis, enrichment factor and factor analysis indicated that anthropogenic sources especially industrial activity, vehicular emission and household cooking are the main sources of trace elements in the study areas. The non-carcinogenic and carcinogenic health risks indicated that children are more vulnerable for non-carcinogenic effects whereas the values of cancer risk for both the child and adult are below the acceptable limit of European Union.
\end{abstract}

Keywords: Indoor air, trace elements, industrial community, health risk, sources, factor analysis

\section{INTRODUCTION}

Bangladesh is an agricultural country; recently economic growth has improved the quality of life for most of the population, but it progressively degrades the environmental quality. The quality of air, water and soil is deteriorated due to different industrial activities such as garments and textile industries, pulp and paper, pharmaceuticals, metal processing, food industry, fertilizers, glass industry, cement industry, dyeing and painting etc. As a result, people living near the industrial areas are more vulnerable to heavy metal pollution. There is an increasing concern about heavy metals contamination in indoor environment as they can enter deep into the lungs and result in serious health effects (Kura et al. 2013). The composition of inhalable particulate matter ( $D_{\text {aerodynamic diameter }} \leq 100 \mu \mathrm{m}$; they enter the respiratory tract including head airways) is complex and differs depending on the source and location. The occurrence of toxic metals such as $\mathrm{Pb}, \mathrm{Zn}, \mathrm{Cu}$, and $\mathrm{Ni}$ in inhalable particulates may contribute to substantial health effects (Safo-Adu et al. 2014). Some of these heavy metals are carcinogenic and mutagenic.

Dust is an important medium that can give information about the level, distribution and fate of contaminants present in the environment. Dust consists of solid matter or particulate in the form of fine powder (less $100 \mu \mathrm{m}$ ), lying on the ground or on the surface of objects or blown about by natural forces or mechanical forces. As the composition of settled dust is similar to atmospheric suspended particulates, it can be also an indicator of pollutants such as heavy metal contamination in the atmosphere (Leung et al. 2008). Indoor dust may contain toxic materials, particularly heavy metals, in quantities that may be potentially harmful to human health (Aucott and Caldarelli 2012). Indoor dust has been found to contain a quantity

*Corresponding author: < mbkhan@bau.edu.bd >.

${ }^{2}$ Chemistry Division, Atomic Energy Centre, Dhaka, Bangladesh 
of heavy metals which may potentially affect the health of young children (Latif et al. 2009). Humans can become exposed to heavy metals in dust through several routes which include ingestion, inhalation, and dermal absorption (Leung et al. 2008).

Therefore, studying on the characteristics dust pollution is not only an important aspect of evaluation of quality of urban environment, but also of great significance for human health. Several researches have been carried out to characterize elemental composition of road dust (Rakib et al. 2014: Dhaka; Ahmed and Ishiga, 2006: Dhaka) but research related to characterization of household dust is limited. Therefore, this research was conducted to fulfill the following objectives (i) to determine the concentration of trace elements in dust deposited at homes near industrial zones, (ii) to assess the possible health risks on residents and (iii) to identify the sources of elements present in indoor air deposited at homes.

\section{MATERIALS AND METHODS}

\section{Study Area}

In this study, fourteen samples were collected from households located near the industrial areas. The features of the sampling sites are given in Table 1 (Map 1). Dust samples were collected into $40 \mathrm{~mL}$ test tube bottles by gently sweeping from different surfaces. The dust samples were screened to remove any visible hair, soil, and grit.

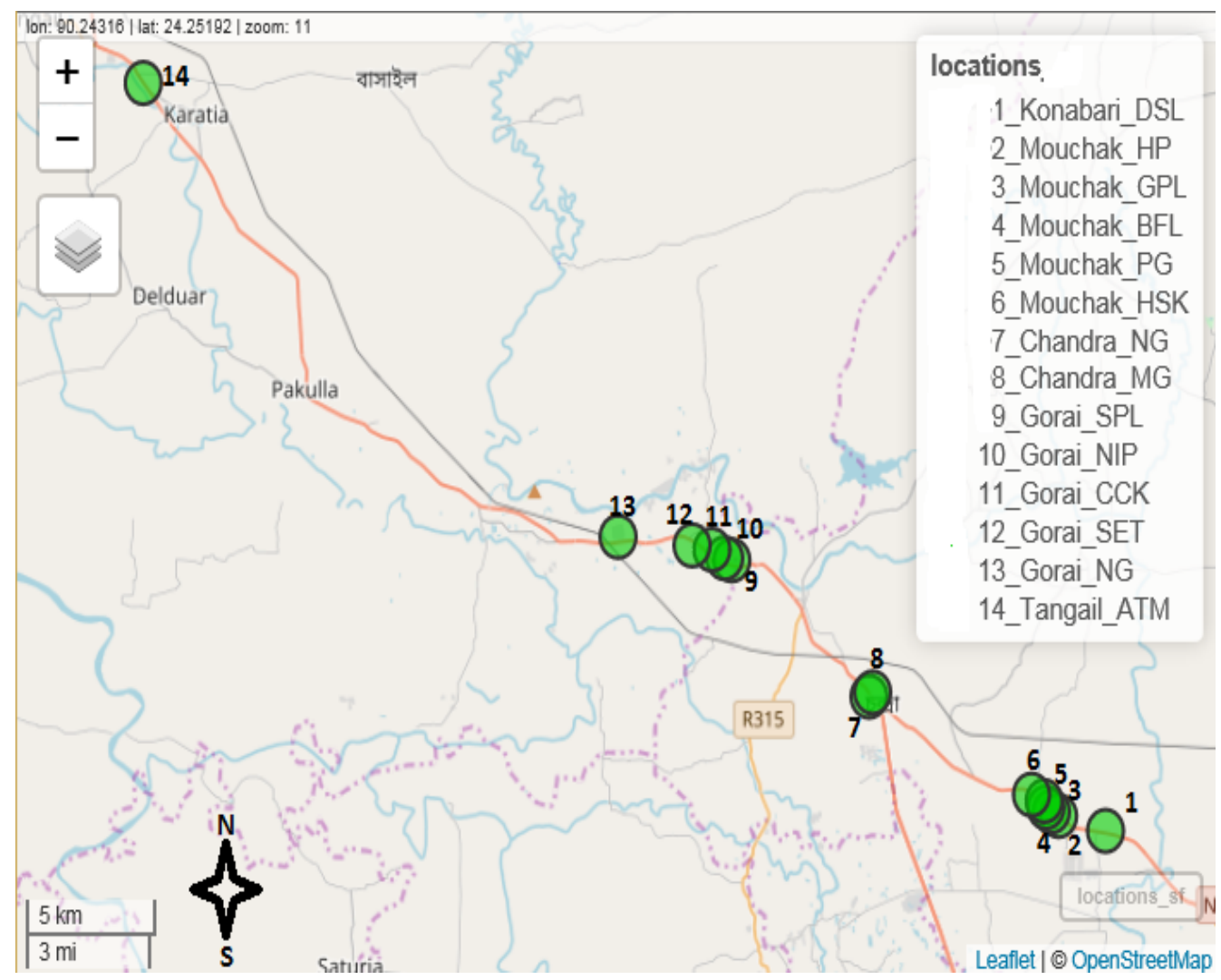

Map 1. Sampling locations of the study area (Details of the locations 1 to 14 are given in Table 1) 
Table 1. Key features of the sampling locations of households located near the industrial areas

\begin{tabular}{|c|c|c|c|c|c|c|}
\hline $\begin{array}{l}\text { Sample } \\
\text { No. }\end{array}$ & Name of Industry & Types of Industry & Place & $\begin{array}{c}\begin{array}{c}\text { Distance } \\
\text { from } \\
\text { Industry }\end{array} \\
\end{array}$ & $\begin{array}{l}\text { Latitude } \\
\text { (Decimal } \\
\text { Degrees) } \\
\end{array}$ & $\begin{array}{l}\text { Longitude } \\
\text { (Decimal } \\
\text { Degrees) } \\
\end{array}$ \\
\hline 1 & $\begin{array}{l}\text { Designtext Sweater } \\
\text { Ltd. }\end{array}$ & Chemicals & Konabari, Gazipur & $300 \mathrm{~m}$. & 24.011099 & 90.323845 \\
\hline 2 & HUSDON pharma & Chemicals & Mouchak, Gazipur & $250 \mathrm{ft}$. & 24.015906 & 90.306378 \\
\hline 3 & $\begin{array}{l}\text { General } \\
\text { Pharmaceuticals } \\
\text { Ltd. }\end{array}$ & Chemicals & $\begin{array}{l}\text { Mouchak, Kaliakur } \\
\text { Gazipur }\end{array}$ & $100 \mathrm{ft}$. & 24.017265 & 90.303375 \\
\hline 4 & $\begin{array}{l}\text { Bay Footwear } \\
\text { Limited \& Agro } \\
\text { Industry }\end{array}$ & Chemicals & $\begin{array}{l}\text { Mouchak, Kaliakur, } \\
\text { Gazipur }\end{array}$ & $350 \mathrm{ft}$. & 24.018505 & 90.30175 \\
\hline 5 & $\begin{array}{l}\text { Purbani Groups } \\
\text { (Karim Textile) }\end{array}$ & $\begin{array}{l}\text { Dyeing(Chemicals), } \\
\text { Garments }\end{array}$ & $\begin{array}{l}\text { Mouchak, Kaliakur, } \\
\text { Gazipur }\end{array}$ & $320 \mathrm{ft}$. & 24.019977 & 90.300454 \\
\hline 6 & $\begin{array}{l}\text { Hydroxite \& } \\
\text { Syntex Knit Wear } \\
\text { Limited }\end{array}$ & Garments & $\begin{array}{l}\text { Mouchak, Kaliakur, } \\
\text { Gazipur }\end{array}$ & $275 \mathrm{ft}$. & 24.022294 & 90.295933 \\
\hline 7 & Nur Group & Dyeing & Chandra, Gazipur & $200 \mathrm{ft}$. & 24.050919 & 90.23444 \\
\hline 8 & Mahmud Group & Dyeing \& Washing & Chandra, Gazipur & $300 \mathrm{ft}$. & 24.051867 & 90.23545 \\
\hline 9 & $\begin{array}{l}\text { SQUARE } \\
\text { Pharmaceuticals } \\
\text { Ltd. }\end{array}$ & Chemicals & $\begin{array}{l}\text { Gorai, Mirzapur, } \\
\text { Tangail }\end{array}$ & $250 \mathrm{ft}$. & 24.090947 & 90.181849 \\
\hline 10 & $\begin{array}{l}\text { Necuage Industrial } \\
\text { Pearls }\end{array}$ & $\begin{array}{l}\text { Garments, } \\
\text { Dyeing(Chemical) }\end{array}$ & $\begin{array}{l}\text { Gorai , Mirzapur, } \\
\text { Tangail }\end{array}$ & $300 \mathrm{ft}$. & 24.91463 & 90.179007 \\
\hline 11 & $\begin{array}{l}\text { Comfit Composite } \\
\text { Knit Limited }\end{array}$ & $\begin{array}{l}\text { T-Shirt Dyeing, } \\
\text { Have EPP }\end{array}$ & $\begin{array}{l}\text { Gorai, Mirzapur, } \\
\text { Tangail }\end{array}$ & $100 \mathrm{ft}$. & 24.094385 & 90.174686 \\
\hline 12 & $\begin{array}{l}\text { South East Texttile } \\
\text { (pvt.) Ltd. }\end{array}$ & Textiles & $\begin{array}{l}\text { Gorai, Mirzapur, } \\
\text { Tangail }\end{array}$ & $150 \mathrm{ft}$. & 24.095072 & 90.16713 \\
\hline 13 & $\begin{array}{l}\text { Nasir Glassware } \\
\text { Tube Industries Ltd }\end{array}$ & $\begin{array}{l}\text { Glass \& Tube, } \\
\text { Chemicals }\end{array}$ & $\begin{array}{l}\text { Gorai, Mirzapur, } \\
\text { Tangail }\end{array}$ & $300 \mathrm{ft}$. & 24.097934 & 90.138715 \\
\hline 14 & $\begin{array}{l}\text { Alauddin Textile } \\
\text { Mills }\end{array}$ & $\begin{array}{l}\text { Textiles, } \\
\text { Dyeing,Chemicals }\end{array}$ & Tangail & $100 \mathrm{ft}$. & 24.23112 & 89.957951 \\
\hline
\end{tabular}

\section{Sample Preparation and Analysis}

Samples were dried in an oven at $70^{\circ} \mathrm{C}$ for overnight in order to free moisture and bottled in clean plastic bottles. Then the samples were analyzed using Energy Dispersive X-ray Fluorescence (EDXRF) at the laboratory of Chemistry division, Bangladesh Atomic Energy Centre, Dhaka, Bangladesh. In the XRF measurements, the samples were processed into $1.0 \mathrm{~cm}$ diameter and $1 \mathrm{~mm}$ thick pellets of weight approximately $0.1 \mathrm{~g}$. Similar procedures were followed for the preparation of standards from IAEA-Soil 7, Montana-1. Here, IAEASoil 7 was used as a standard and Montana-1 was used as the quality assurance and quality control (QA/QC) in the measurement process.
The minimum detection limit (MDL) of the method has been determined with Montana-1 standard for $1000 \mathrm{sec}$ irradiation time.

\section{Health risk Assessment}

Elements entered into human body through three exposure pathways: (a) ingestion, (b) dermal contact, and ( c) inhalation (Ferreira-Baptista and Miguel 2005; Kurt-Karakus 2012). The potential exposure doses through ingestion, inhalation and dermal contact were calculated from the following equations (Eq.) as recommended by USEPA (1989). The exposure parameters used for the calculation of health risk assessment are given in Table 2 . 
Daily potential exposure dose through ingestion

$$
\begin{aligned}
A D I_{\text {ing }} & =\frac{C \times I R \times E F \times E D \times C F}{B W \times A T} \\
A D I_{\text {inh }} & =\frac{C \times I R_{\text {air }} \times E F \times E D}{B W \times A T \times P E F} \\
A D I_{\text {der }} & =\frac{C \times S A \times F E \times A F \times A B S \times E F \times E D \times C F}{B W \times A T}(E q .3)
\end{aligned}
$$

Daily potential exposure dose through inhalation

dose through dermal contact

Finally, non-carcinogenic and carcinogenic risk were calculated from the term described by USEPA and is given in Eq. 4 and Eq. 5.

\section{Non-carcinogenic Risk Assessment}

Hazard quotient $(\mathrm{HQ})=\frac{A D I}{R f D}(E q .4)$

where $\mathrm{ADI}=$ Exposure Dose

$\mathrm{RfD}=$ Chronic Reference Dose in $\mathrm{mg} / \mathrm{kg}$-day of a heavy metal

\section{Carcinogenic Risk Assessment}

Cancer Risk $(C R)=A D I_{k} \times C S F_{k}(E q .5)$

where $A D I_{k}=$ The average daily intake for kth trace element

$C S F_{k}=$ Cancer slope factor for $\mathrm{n}$ number of trace element

\begin{tabular}{|c|c|c|c|c|}
\hline Parameter & Definition & Child & Adult & References \\
\hline $\mathrm{C}$ & $\begin{array}{l}\text { Average concentration of HMs in } \\
\text { APM }(\mathrm{mg} / \mathrm{kg})\end{array}$ & & & Hu et al. (2012) \\
\hline$\overline{B W}$ & Body Weight (kg) & 15 & 70 & USEPA(2004) \\
\hline $\mathrm{EF}$ & Exposure frequency (days/year) & 350 & 350 & DoEA (2010) \\
\hline $\mathrm{ED}$ & Exposure duration (year) & 6 & 30 & DoEA (2010) \\
\hline IR & Ingestion rate (mg/day) & 200 & 100 & DoEA (2010) \\
\hline IRair & Inhalation rate (m³/day) & 10 & 20 & DoEA (2010) \\
\hline SA & Skin surface area $\left(\mathrm{cm}^{2}\right)$ & 2100 & 5800 & DoEA (2010) \\
\hline $\mathrm{AF}$ & Soil adherence factor $\left(\mathrm{mg} / \mathrm{cm}^{2}\right)$ & 0.2 & 0.07 & DoEA (2010) \\
\hline ABS & Dermal Absorption factor & 0.1 & 0.1 & DoEA (2010) \\
\hline $\mathrm{FE}$ & Dermal Exposure ration & 0.61 & 0.61 & DoEA (2010) \\
\hline PEF & Particulate emission factor $\left(\mathrm{m}^{3} / \mathrm{kg}\right)$ & $1.3 \times 10^{9}$ & $1.3 \times 10^{9}$ & DoEA (2010) \\
\hline $\mathrm{CF}$ & Conversion factor (kg/mg) & $10^{-6}$ & $10^{-6}$ & DoEA (2010) \\
\hline \multirow{2}{*}{ AT } & $\begin{array}{l}\text { Averaging Time: For carcinogens } \\
\text { (days) }\end{array}$ & $365 \times 70$ & $365 \times 70$ & DoEA (2010) \\
\hline & For non-carcinogens (days) & $365 \times \mathrm{ED}$ & $365 \times \mathrm{ED}$ & DoEA (2010) \\
\hline
\end{tabular}

Table 2. Recommended values of the parameters used to calculate the daily exposure dose of trace elements in Dust 


\section{RESULTS AND DISCUSSION}

Characterization of indoor air deposited at

homes in industrial community

The mean concentration of potassium $(\mathrm{K})$ was $10892 \mathrm{mg} \mathrm{kg}^{-1}$ and ranged from $4668 \mathrm{mg} \mathrm{kg}^{-1}$ to14665 $\mathrm{mg} \mathrm{kg}^{-1}$. The higher concentration of $\mathrm{K}$ was observed in samples S14, S13, S12 and S2, whereas the lower concentration was found in samples S1 and S9 (Table 3). In this study, the higher concentration of potassium was found in several locations especially near Alauddin Textile mill (S14), Tangail. Biomass burning in household activities may be the main reason of the availability of $\mathrm{K}$ in that area. The concentration of Calcium $(\mathrm{Ca})$ ranged from $14280 \mathrm{mg} \mathrm{kg}^{-1}$ to $44845 \mathrm{mg} \mathrm{kg}^{-1}$ whereas the mean value of $\mathrm{Ca}$ concentration is $30898 \mathrm{mg}$ $\mathrm{kg}^{-1}$. The higher concentration of calcium was observed in several locations especially near SQUARE Pharmaceuticals Ltd. which is located in Mirzapur, Tangail. The observed mean concentration of Ti was $4349 \mathrm{mg} \mathrm{kg}^{-1}$ and varied between $2753 \mathrm{mg} \mathrm{kg}^{-1}$ to $5401 \mathrm{mg} \mathrm{kg}^{-1}$. The higher concentration of $\mathrm{Ti}$ was observed in S13, S14, S5 and S6 samples whereas the lower concentrations were found in samples S1 and S5 (Table 3). The average Fe concentration was $57435 \mathrm{mg} \mathrm{kg}^{-1}$ and fluctuated from $36080 \mathrm{mg}$ $\mathrm{kg}^{-1}$ to $171780 \mathrm{mg} \mathrm{kg}^{-1}$. The highest $\mathrm{Fe}$ concentration was observed in S3 whereas the lower $\mathrm{Fe}$ concentration was observed in all remaining samples except S4 (Table 3). The highest concentration of $\mathrm{Fe}$ was found in Designtext Sweater Ltd that is situated in Konabari, Gazipur. Natural source was considered as main source of iron in this region. $\mathrm{Fe}$ is an abundant element in the earth crust (Al-Khashman 2004). The concentration of $\mathrm{Cu}$ ranged from $16 \mathrm{mg} \mathrm{kg}^{-1}$ to $41 \mathrm{mg} \mathrm{kg}^{-1}$ and its mean value was $25 \mathrm{mg} \mathrm{kg}^{-1}$. However the higher $\mathrm{Cu}$ concentration was found in samples $\mathrm{S} 2$ and S14 whereas the lower concentration was detected in samples S5, S11 and S13 (Table 3). Street dust was the major source of $\mathrm{Cu} . \mathrm{Cu}$ is usually emitted in the environment through combustion of fuel. The observed mean value of Zinc concentration was $1718 \mathrm{mg} \mathrm{kg}^{-1}$ and it varied from $561 \mathrm{mg} \mathrm{kg}^{-1}$ to $5863 \mathrm{mg} \mathrm{kg}^{-1}$. The highest Zinc concentration was found in sample $\mathrm{S} 2$ whereas the lower Zinc concentration was observed in samples S5, S8, S12, S13 and S14 (Table 3). The accumulation of $\mathrm{Zn}$ emitted from tyres, motor oil and the usage of motor vehicle brakes (Han et al. 2011). The average value of As concentration was $9 \mathrm{mg} \mathrm{kg}^{-1}$ which ranged from $6 \mathrm{mg} \mathrm{kg}^{-1}$ to $12 \mathrm{mg} \mathrm{kg}^{-1}$. On the basis of result, higher concentration of As was found in the samples S2, S6, S7 and S9 whereas the lower concentration of As was observed in S1, S5, S13 and S14 (Table 3). Natural source was considered as main source of As contamination in the earth. Comparing with different locations, the observed mean value of $\mathrm{Rb}$ concentration was $126 \mathrm{mg} \mathrm{kg}^{-1}$ and it ranged from $71 \mathrm{mg} \mathrm{kg}^{-1}$ to $284 \mathrm{mg} \mathrm{kg}^{-1}$. The highest $\mathrm{Rb}$ concentration was found in sample $\mathrm{S} 14$ whereas the lower Rb concentration was found in samples S1, S3, S9 and $\mathrm{S} 10$. In this study the highest $\mathrm{Rb}$ ion concentration was observed near Alauddin Textile Mills at Tangail. Data studied represent mean value of strontium $(\mathrm{Sr})$ concentration was $155 \mathrm{mg} \mathrm{kg}^{-1}$ and it ranged from $106 \mathrm{mg} \mathrm{kg}^{-1}$ to $202 \mathrm{mg} \mathrm{kg}^{-1}$. In this study the highest $\mathrm{Sr}$ ion concentration was observed in several locations especially near Bay Footwear Limited \& Agro Industry at Mouchak, Kaliakur, Gazipur. The average concentration of Ytrium (Y) was $24 \mathrm{mg}$ $\mathrm{kg}^{-1}$ and it ranged from $15 \mathrm{mg} \mathrm{kg}^{-1}-37 \mathrm{mg} \mathrm{kg}^{-1}$. Higher Y concentration was observed in several locations especially near General Pharmaceuticals Ltd at Kaliakur, Gazipur. Y may originate from paint along with gaps and cracks in walls and building materials (Tong and Lam 2000). Mean Zirconium (Zr) concentration was $238 \mathrm{mg} \mathrm{kg}^{-1}$ and it ranged from 142 to 474 
$\mathrm{mg} \mathrm{kg}^{-1}$. The highest $\mathrm{Zr}$ concentration was observed in several locations especially near General Pharmaceuticals Ltd. at Kaliakur, Gazipur. $\mathrm{Zr}$ was identified as anthropogenic sources in road dust (Atiemo et al. 2011). The observed mean concentration of $\mathrm{Pb}$ was 310 $\mathrm{mg} \mathrm{kg}^{-1}$ and it varied from $202 \mathrm{mg} \mathrm{kg}^{-1}$ to 785 $\mathrm{mg} \mathrm{kg}^{-1}$. In this study the highest concentration of lead was observed in near Alauddin Textile Mills, at Tangail. $\mathrm{Pb}$ is also frequently used in different industries such as dyes and paints.

Table 3. Concentration of trace elements present in household dust (mgkg $\left.{ }^{-1}\right)$

\begin{tabular}{|c|c|c|c|c|c|c|c|c|c|c|c|c|c|c|}
\hline Sample & $\mathbf{K}$ & $\mathrm{Ca}$ & $\mathbf{T i}$ & $\mathrm{Cr}$ & $\mathrm{Fe}$ & $\mathbf{N i}$ & $\mathrm{Cu}$ & $\mathbf{Z n}$ & As & $\mathbf{R b}$ & $\mathrm{Sr}$ & $\mathbf{Y}$ & $\mathbf{Z r}$ & $\mathbf{P b}$ \\
\hline S1 & 4668 & 18555 & 2753 & $<5.2$ & 36080 & $<0.19$ & 23 & 2171 & 6 & 86 & 125 & 23 & 187 & 233 \\
\hline $\mathrm{S} 2$ & 13230 & 35455 & 4256 & $<5.2$ & 45095 & $<0.19$ & 37 & 5863 & 7 & 120 & 176 & 23 & 177 & 417 \\
\hline S3 & 10154 & 33115 & 4290 & $<5.2$ & 171780 & $<0.19$ & 30 & 1707 & 7 & 71 & 106 & 17 & 159 & 225 \\
\hline S4 & 10410 & 33560 & 4179 & $<5.2$ & 75285 & $<0.19$ & 29 & 2790 & 6 & 116 & 191 & 25 & 250 & 273 \\
\hline S5 & 8396 & 14280 & 4972 & $<5.2$ & 38265 & $<0.19$ & 20 & 667 & 6 & 144 & 108 & 37 & 474 & 202 \\
\hline S6 & 12660 & 36840 & 4860 & $<5.2$ & 49705 & $<0.19$ & 22 & 1180 & 7 & 134 & 202 & 36 & 365 & 219 \\
\hline S7 & 11990 & 41205 & 4070 & $<5.2$ & 47680 & $<0.19$ & 22 & 1209 & 6 & 123 & 180 & 30 & 285 & 213 \\
\hline S8 & 11002 & 34445 & 4779 & $<5.2$ & 44130 & $<0.19$ & 22 & 765 & 10 & 135 & 173 & 28 & 269 & 326 \\
\hline S9 & 7856 & 44845 & 2764 & $<5.2$ & 50785 & $<0.19$ & 27 & 1324 & 10 & 82 & 130 & 16 & 164 & 280 \\
\hline S10 & 9442 & 34570 & 3969 & $<5.2$ & 41885 & $<0.19$ & 22 & 2194 & 12 & 106 & 156 & 26 & 243 & 378 \\
\hline S11 & 10005 & 37405 & 4865 & $<5.2$ & 48100 & $<0.19$ & 18 & 2208 & 12 & 116 & 166 & 26 & 217 & 289 \\
\hline $\mathrm{S} 12$ & 13840 & 28510 & 4672 & $<5.2$ & 47225 & $<0.19$ & 20 & 561 & 11 & 122 & 166 & 16 & 142 & 248 \\
\hline S13 & 14165 & 19230 & 5401 & $<5.2$ & 55700 & $<0.19$ & 16 & 558 & 12 & 129 & 121 & 15 & 153 & 259 \\
\hline S14 & 14665 & 20550 & 5051 & $<5.2$ & 52370 & $<0.19$ & 41 & 853 & 12 & 284 & 163 & 24 & 242 & 785 \\
\hline Mean & 10892 & 30898 & 4349 & & 57435 & & 24.9 & 1717.9 & 8.9 & 126.3 & 154.5 & 24.4 & 237.6 & 310.5 \\
\hline
\end{tabular}




\section{Sources of Elements Present in Indoor Air Deposited at Homes}

A Pearson correlation was conducted to observe the relationship among metals. The correlation coefficient of the analysis is given in Table 4. Strong correlation was observed between pairs of $\mathrm{Y}-\mathrm{Zr}(\mathrm{r}=0.93), \mathrm{Pb}-\mathrm{Rb}(\mathrm{r}=0.82), \mathrm{K}-\mathrm{Ti}(\mathrm{r}=0.73)$ and $\mathrm{Cu}-\mathrm{Pb} \quad(\mathrm{r}=0.73)$. Statistically significant relationship was also observed between pairs of $\mathrm{K}-\mathrm{Rb}$, Ti-Rb and $\mathrm{Ca}-\mathrm{Sr}$. This significant relationship indicated that these metals may be emitted from the same sources. the mean concentrations of the metals and the reference metal in the Earth's crust, respectively. An element is considered to be crustal origin if $\mathrm{EF}<1$, while the element is supposed to be noncrustal origin for $\mathrm{EF}$ value greater than 5 (Gao et al. 2002). Usually $\mathrm{Al}, \mathrm{Fe}, \mathrm{Si}$ and $\mathrm{Ti}$ are given priorities as reference materials because of lacking of predominant anthropogenic sources (Petaloti et al. 2006). In this study, Fe is selected as reference material (Alves et al. 2015) and the calculated EFs of metals are given in Fig. 1. Considering all sites, the most enriched elements $(\mathrm{EF}>5)$ were $\mathrm{Zn}, \mathrm{Pb}$ and $\mathrm{As}$

Correlations among elements

Table 4. A correlation matrix between different elements

\begin{tabular}{|c|c|c|c|c|c|c|c|c|c|c|c|c|}
\hline & $\mathbf{K}$ & $\mathrm{Ca}$ & $\mathbf{T i}$ & $\mathrm{Fe}$ & $\mathrm{Cu}$ & $\mathbf{Z n}$ & As & $\mathbf{R b}$ & $\mathrm{Sr}$ & $\mathbf{Y}$ & $\mathbf{Z r}$ & $\mathrm{Pb}$ \\
\hline $\mathrm{K}$ & 1.00 & & & & & & & & & & & \\
\hline $\mathrm{Ca}$ & 0.03 & 1.00 & & & & & & & & & & \\
\hline $\mathrm{Ti}$ & $0.73^{*}$ & -0.32 & 1.00 & & & & & & & & & \\
\hline $\mathrm{Fe}$ & 0.25 & 0.22 & 0.13 & 1.00 & & & & & & & & \\
\hline $\mathrm{Cu}$ & 0.23 & 0.06 & -0.13 & 0.29 & 1.00 & & & & & & & \\
\hline $\mathrm{Zn}$ & -0.06 & 0.28 & -0.28 & 0.04 & 0.47 & 1.00 & & & & & & \\
\hline As & 0.36 & 0.00 & 0.32 & -0.11 & -0.12 & -0.29 & 1.00 & & & & & \\
\hline $\mathrm{Rb}$ & 0.56 & -0.39 & 0.53 & -0.08 & 0.46 & -0.24 & 0.33 & 1.00 & & & & \\
\hline $\mathrm{Sr}$ & 0.44 & 0.50 & 0.18 & 0.06 & 0.15 & 0.25 & -0.02 & 0.25 & 1.00 & & & \\
\hline $\mathrm{Y}$ & -0.11 & -0.05 & 0.24 & -0.35 & -0.13 & -0.04 & -0.42 & 0.23 & 0.36 & 1.00 & & \\
\hline $\mathrm{Zr}$ & 0.12 & -0.21 & 0.31 & -0.28 & -0.17 & -0.24 & -0.39 & 0.27 & 0.13 & $0.93^{*}$ & 1.00 & \\
\hline $\mathrm{Pb}$ & 0.42 & -0.17 & 0.20 & -0.02 & $0.73^{*}$ & 0.12 & 0.46 & $0.82^{*}$ & 0.19 & -0.09 & -0.12 & 1.00 \\
\hline
\end{tabular}

- Data with star sign (*) showed statistically significant relationship.

\section{Enrichment Factors}

Enrichment factors indicate the source of a metal in a particular place. Usually, the enrichment of metals in atmospheric particles relativel to the upper surface dust composition is an indication of emissions from anthropogenic sources. The enrichment factor (EF) for the metals was calculated using the following equation:

$$
E F=\frac{[\mathrm{E}] \mathrm{atm} /[\mathrm{R}] \mathrm{atm}}{[\mathrm{E}] \text { soil } /[\mathrm{R}] \text { soil }}
$$

Where $[\mathrm{E}]_{\mathrm{atm}}$ and $[\mathrm{R}]_{\mathrm{atm}}$ are the mean concentrations of the metals and the reference metal in the atmosphere, and $[\mathrm{E}]_{\text {soil }}$ and $[\mathrm{R}]_{\text {soil }}$ are suggesting that these elements are mainly coming to the atmosphere from the emissions of various anthropogenic activities. Major sources of these elements are considered to be automotive emissions and biomass burning. Low $\mathrm{EF}$ values $(<5)$ were found for $\mathrm{K}, \mathrm{Ca}, \mathrm{Ti}, \mathrm{Cu}$, $\mathrm{Rb}, \mathrm{Sr}, \mathrm{Y}, \mathrm{Zr}$ at all sampling sites revealing that these elements may originate mainly from soil or road dust re-suspension. In general, metals that are distributed mostly in fine particles show high $\mathrm{EF}$ values whereas elements linked with coarse particles give lower EF values. 
EF

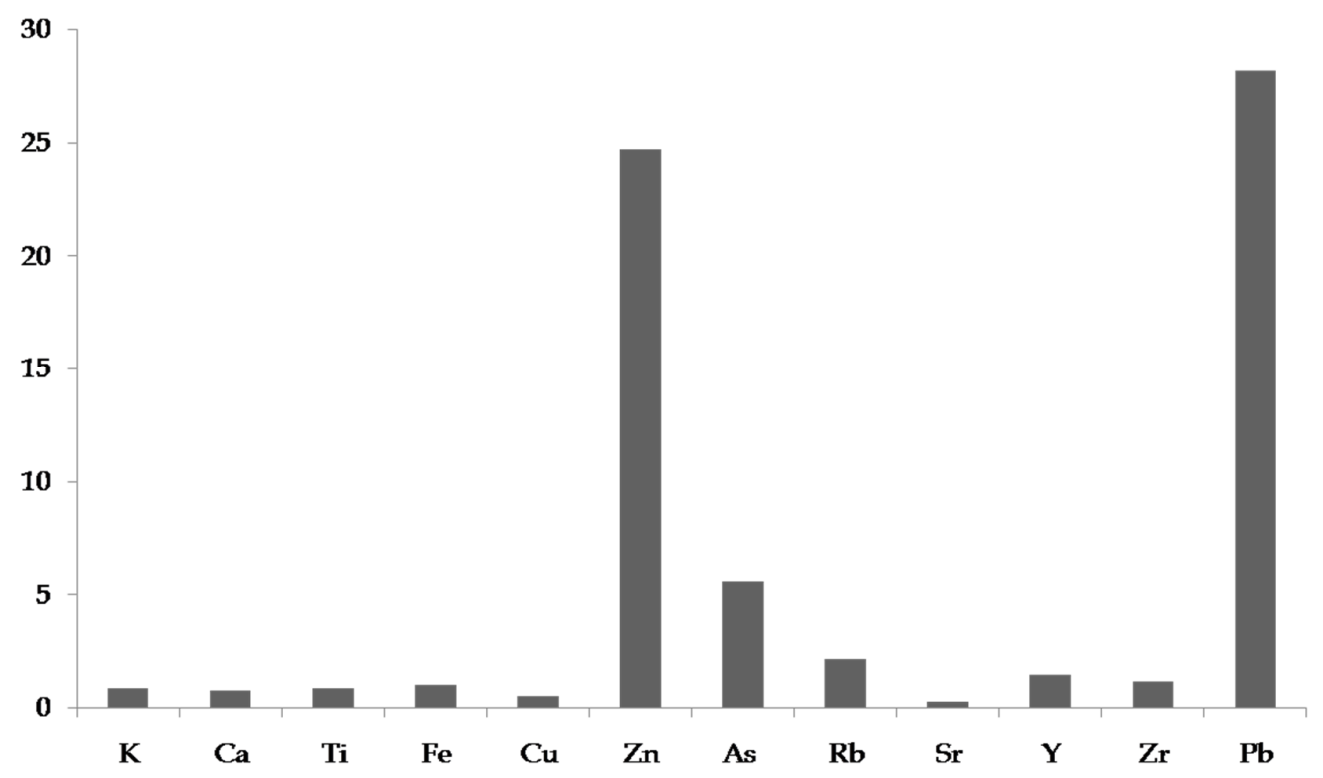

Fig. 1. Enrichment factors $(\mathrm{EF})$ of the elements collected from households

\section{Factor Analysis}

To quantify possible sources of household dust, a statistical procedure named Factor Analysis (FA) was performed to identify number of factors and species profile of each source. Main principle of the FA is to reduce the number variables keeping original information. Factors were identified using varimax rotation method based on eigen-value, scree plot, variability in the number of factors and sensibility of each variable to factor loading. Variables were considered as sources when factor loading were $>0.75$. Potential sources of household dust were identified and are given in Table 5. The first factor includes $\mathrm{Cu}$ and $\mathrm{Pb}$. The chemical $\mathrm{Cu}$ and $\mathrm{Pb}$ are the predominant sources of vehicular emission (Cheng et al. 2010). Therefore this factor is designed as vehicular emission. Dust from brake/tire wear contained $\mathrm{Cu}$ and $\mathrm{Pb}$. Factor 2 comprised of $\mathrm{Y}$ and $\mathrm{Zr}$. Yttrium (Y) and
$\mathrm{Zr}$ are considered as both natural and anthropogenic oriented chemicals. So this has beer denoted as mixed source. However, the other sources of $\mathrm{Zr}$ are heat-shock, furnace linings, foundry bricks, abrasives glass and ceramics industries, scissors and knives, cosmetics, antiperspirants, food packaging and microwave filters. The most common uses of yttrium are LEDs and phosphate, especially the red phosphors in television set. In Factor 3, the highest loading was observed in $\mathrm{Ca}$ and $\mathrm{Sr}$. Construction industry such as cement may be the possible source of $\mathrm{Ca}$ and $\mathrm{Sr}$. The $4^{\text {th }}$ Factor concludes $\mathrm{K}$ and Ti. Biomass burning in household's actives may be the possible source of $\mathrm{K}$ in that area. On the contrary, Ti was recognized as anthropogenic source such as road dust, natural crustal, vehicular emissions, and corroded vehicular parts (Atiemo et al. 2011). 
Table 5. Variables with loading in factor analysis at Tangail and Gazipur. (Variables with loading factors $>0.75$ are bold marked)

\begin{tabular}{|c|c|c|c|c|}
\hline Chemical & Factor 1 & Factor 2 & Factor 3 & Factor 4 \\
\hline $\mathrm{K}$ & 0.28 & 0.11 & 0.33 & 0.81 \\
\hline $\mathrm{Ca}$ & -0.18 & 0.17 & 0.81 & -0.15 \\
\hline $\mathrm{Ti}$ & 0.02 & -0.23 & -0.02 & 0.86 \\
\hline $\mathrm{Fe}$ & 0.03 & 0.39 & 0.42 & 0.12 \\
\hline $\mathrm{Cu}$ & 0.91 & 0.12 & 0.20 & -0.16 \\
\hline $\mathrm{Zn}$ & 0.41 & 0.07 & 0.48 & -0.50 \\
\hline As & 0.06 & 0.49 & -0.21 & 0.62 \\
\hline $\mathrm{Rb}$ & 0.68 & -0.26 & -0.20 & 0.61 \\
\hline $\mathrm{Sr}$ & 0.17 & -0.30 & 0.78 & 0.29 \\
\hline $\mathrm{Y}$ & -0.02 & -0.98 & 0.09 & 0.02 \\
\hline $\mathrm{Zr}$ & -0.08 & -0.95 & -0.11 & 0.09 \\
\hline $\mathrm{Pb}$ & 0.90 & 0.10 & -0.10 & 0.33 \\
\hline$\%$ Variance & 2.44 & 2.49 & 1.78 & 2.62 \\
\hline $\begin{array}{c}\text { Cumulative } \\
\text { Variance }\end{array}$ & 20 & 21 & 15 & 22 \\
\hline Sources & $\begin{array}{l}\text { Vehicular } \\
\text { emission }\end{array}$ & Mixed Sources & $\begin{array}{l}\text { Construction } \\
\text { industry }\end{array}$ & $\begin{array}{l}\text { Household } \\
\text { combustion }\end{array}$ \\
\hline
\end{tabular}

Non-carcinogenic and carcinogenic health risk

Non-carcinogenic risk for an element is expressed by the term called hazard quotient (HQ) whereas the non-carcinogenic effect to the population is calculated by the term Hazard Index that is the result of the summation of all the HQs due to individual element. People are risked for possible non-carcinogenic effects, if HQ and HI values exceed 1. For a child, the HQ values are higher than 1 for ingestion pathways mainly due to $\mathrm{Pb}$ whereas it is less than 1 for both inhalation and dermal pathways (Fig. 2a). For adult, the calculated HI value is less than 1, indicating that the exposured population are not risk for non-carcinogenic effects. The cancer risk of $\mathrm{Pb}$ and $\mathrm{As}$ has been estimated from the average daily exposure doses for both child and adult population (Fig. 2b). The values of cancer risk for both the trace elements are below the acceptable limit of European Union $\left(10^{-6}\right.$ to $10^{-4}$ per year: EC 2001), indicated that these two elements are not responsible for carcinogenic risk. 
Fig. 2. Non-carcinogenic and carcinogenic risk due to the exposure of trace elements

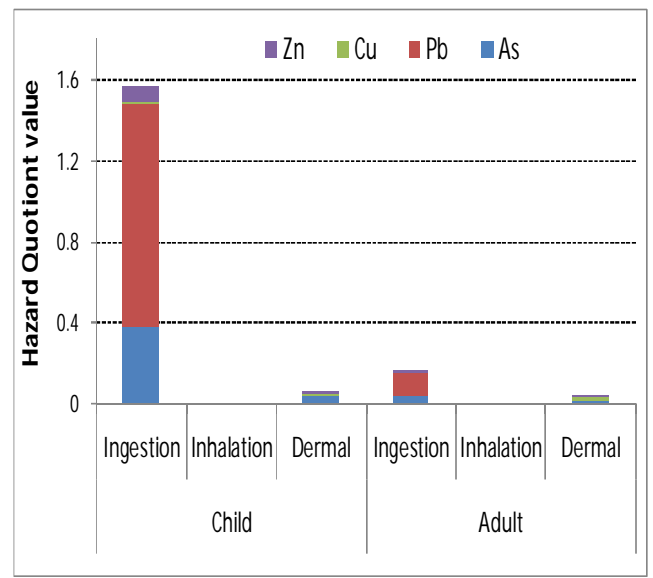

Fig. 2a. Hazard Quotient (HQ) values of trace element for child and adult

\section{CONCLUSION}

Trace element concentration at homes in industrial-zones may vary from place to place depending on pollutant types and accumulation and/or depositional factor. The highest concentration was observed for $\mathrm{Fe}$ whereas the overall rank of the concentrations is $\mathrm{Fe}>\mathrm{Ca}>\mathrm{K}>\mathrm{Ti}>\mathrm{Zn}>\mathrm{Pb}>\mathrm{Zr}>\mathrm{Sr}>\mathrm{Rb}>\mathrm{Cu}>\mathrm{Y}>\mathrm{As}>\mathrm{Cr}$ $>\mathrm{Ni}$. Generally, trace element concentrations in indoor dust are in the range of the corresponding values reported in literature for a variety of locations. Correlation analysis, enrichment factors and factor analysis were performed to identify the possible sources of indoor dust. Strong correlation was observed between pairs of $\mathrm{Y}-\mathrm{Zr}(\mathrm{r}=0.93), \mathrm{Pb}-\mathrm{Rb}(\mathrm{r}=0.82), \mathrm{K}-\mathrm{Ti}$ $(\mathrm{r}=0.73)$ and $\mathrm{Cu}-\mathrm{Pb}(\mathrm{r}=0.73)$. Statistically significant relationship was also observed between pairs of $\mathrm{K}-\mathrm{Rb}$, Ti-Rb and $\mathrm{Ca}-\mathrm{Sr}$. This significant relationship indicates that these metals may originate from the same sources. Enrichment Factors might be attributed to different anthropogenic sources of the metals in the indoor environments.

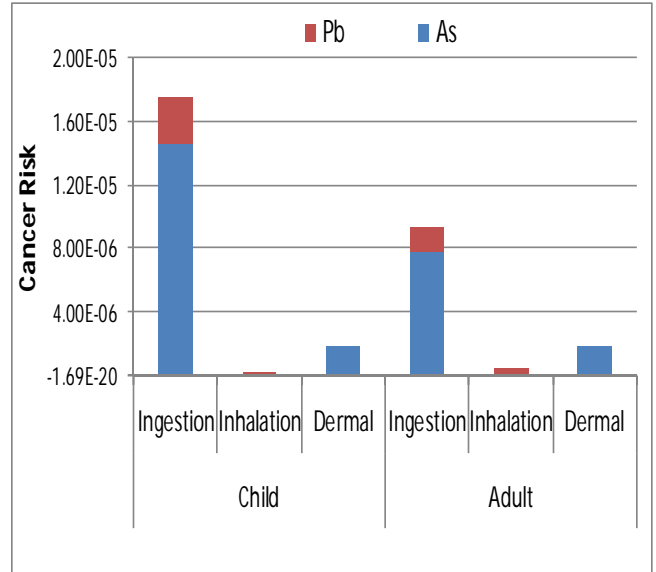

Fig. 2b. Cancer risk values of trace elements for child and adult

From the results it could be concluded that the concentration of different chemicals in the study areas may have originated from the earlier industrial activities and also vehicular emissions. Possible sources of metals were identified by the statistical procedure named factor analysis and it indicated that main source of $\mathrm{Cu}$ and $\mathrm{Pb}$ were from vehicular emission whereas main source of $\mathrm{Ca}$ and $\mathrm{Sr}$ were from construction works or from cement industry. The non-carcinogenic and carcinogenic health risks were calculated and indicated that children are more vulnerable for non-carcinogenic effects whereas the values of cancer risk for both the child and adult are below the acceptable limit of European Union $\left(10^{-6}\right.$ to $10^{-4}$ per year).

\section{REFERENCES}

Ahmed F and H. Ishiga. 2006: Trace Metals Concentration in Street Dusts of Dhaka City Bangladesh. Atmos. Environ. 40: 38353844. 
Al-Khashman, A.O. 2004. Heavy Metal Distribution in Dust, Street Dust and Soils from the work Place in Korak Industrial Estate. Jordan J. Atmos. Environ., 38: 68036812.

Alves, C.A., J. Gomez, T. Nunes, M. Duarte, A. Calvo and D. Custódio. et al. 2015. Sizesegregated particulate matter and gaseous emissions from motor vehicles in a road tunnel. Atmos. Res. 153: 134-144.

Atiemo, M.S., O. G. Francis, K. H. Mensah, T. A. Osei and T. Sherene. 2010 / 2011. Mobility and transport of heavy metals in polluted soil environment. Int. J. Biol. For. 2(2): 112-121.

Aucott, M. and A. Caldarelli. 2012. Quantity of Lead Released to the Environment in New Jersey in the Form of Motor Vehicle Wheel Weights. Water Air Soil Poll. 223(4): 17431752 .

Cheng, Y., S. C. Lee, K. F. Ho, J. C. Chow, J. G. Watson, P. K. K. Louie, J. J. Cao and X. Hai. 2010. Chemically-speciated on-road $\mathrm{PM}_{2.5}$ motor vehicle emission factors in Hong Kong. Sci. Tot. Environ. 408(7): 1621-1627.

DoEA (Department of Environmental Affairs). 2010. The Framework for the Management of Contaminated Land, South Africa.

Ferreira-Baptista L and E. D. Miguel. 2005. Geochemistry and risk assessment of street dust in Luanda, Angola: a tropical urban environment. Atmos. Environ. 39: 4501-4512.

Gao, Y., E. D. Nelson, M. P. Field, Q. Ding, H. Li and R. M. Sherrell et al. 2002. Characterization of atmospheric trace elements on $\mathrm{PM}_{2.5}$ particulate matter over the NewYork-New Jersey harbor estuary. Atmos. Environ. 36:1077-1086.
Han, S., H. Bian, Y. Feng, A. Liu, X, Li, F. Zeng and X. Zhang. 2011. Analysis of the relationship between $\mathrm{O}_{3}$, $\mathrm{NO}$ and $\mathrm{NO}_{3}$ in Tianjin, China. Aerosol Air Qual Res. 11(2): $128-139$

Hu X, Y. Zhang, Z. Ding, T. Wang, H. Lian and Y. Sun et al. 2012. Bioaccessibility and health risk of arsenic and heavy metals $(\mathrm{Cd}$, $\mathrm{Co}, \mathrm{Cr}, \mathrm{Cu}, \mathrm{Ni}, \mathrm{Pb}, \mathrm{Zn}$ and $\mathrm{Mn}$ ) in TSP and PM2.5 in Nanjing, China. Atmospheric Environment 57: 146-152.

Kura, B., S. Verma, E. Ajdari and A. Iyer. 2013. Growing Public Health Concerns from Poor Urban Air Quality: Strategies for Sustainable Urban Living. Comp. Water, Energy, Environ.Eng., 2: 1-9.

Kurt-Karakus P. B. 2012. Determination of heavy metals in indoor dust from Istanbul, Turkey: Estimation of the health risk. Environmental International 50: 47-55.

Latif, M.T., S. A. Ngah, D. Dominick, I. S. Razak, X. Guo, T. Srithawirat and I. Mushrifah. 2015. Composition and source apportionment of dust fall around a natural lake. J. Environ. Sci. 33: 143-155.

Leung, A.O.W., N. S. Duzgoren-Aydin, K. C. Cheung and M. H. Wong. 2008. Heavy metals concentrations of surface dust from e-waste recycling and its human health implications in Southeast China. Environs. Sci. Technol. 42(7) 2674-2680.

Petaloti, C., A. Triantafyllou, T. Kouimtzis and C. Samara. 2006. Trace elements in atmospheric particulate matter over a coal burning power production area of western Macedonia, Greece. Chemosphere 65: 22332243. 
Rakib, M. A., M. Ali, M. S. Akter and M. A. H. Bhuiyan. 2014: Assessment of Heavy Metal $(\mathrm{Pb}, \mathrm{Zn}, \mathrm{Cr}$ and $\mathrm{Cu})$ Content in Roadside Dust of Dhaka Metropolitan City, Bangladesh. Int. Res. J. Environ. Sci. 3(1): 1-5.

Safo-Adu, G., F. G. Ofosu, D. Carboo and Y. S. Armah. 2014. Heavy metals and black carbon assessment of $\mathrm{PM}_{10}$ particulates along Accra-Tema Highway in Ghana. Int. J. Sci. Technol., 3: 467-474.

Tong, S.T.Y. and K. C. Lam, K.C. 2000. Home sweet home? A case study of indoor dust contamination in Hong Kong. Sci. Tot. Environ. 256: 115-123.
U.S. Environmental Protection Agency. Risk Assessment Guidance for Superfund Volume 1: Human Health Evaluation Manual (Part A); Office of Emergency and Remedial Response: Washington, DC, USA, 1989.

USEPA (United States Environmental Protection Agency). 2004. Risk Assessment Guidance for Superfund Volume I: Human Health Evaluation Manual (Part E, Supplemental Guidance for Dermal Risk Assessment). Office of Superfund Remediation and Technology Innovation, Washington, D.C.

(Received revised manuscript on 12 April 2019) 